\title{
Exchange Rate Volatility and Economic Growth
}

\author{
Achouak Barguellil \\ University of Tunis El Manar, Tunis, Tunisia \\ Ousama Ben-Salha \\ Northern Border University, Arar, Saudi Arabia \& University of Sousse, Sousse, Tunisia \\ Mourad Zmami \\ Northern Border University, Arar, Saudi Arabia \& University of Tunis, Tunis, Tunisia
}

\begin{abstract}
This paper examines the impact of exchange rate volatility on economic growth. An empirical investigation based on a sample of 45 developing and emerging countries over the period of 1985 2015 is conducted using the difference and system generalized method of moments estimators. Findings suggest that the generalized autoregressive conditional heteroskedasticity-based measure of nominal and real exchange rate volatility has a negative impact on economic growth. Also, the effect of exchange rate volatility depends on the exchange rate regimes and financial openness, that is, volatility is more harmful when countries adopt flexible exchange rate regimes and financial openness.
\end{abstract}

JEL Classifications: F43, F31, C23

Keywords: Economic Growth, Exchange Rate Volatility, Developing Countries, Financial Openness, Exchange Rate Regime

\footnotetext{
* Corresponding Author: Ousama Ben-Salha; Northern Border University, Ar'ar, 91431, Saudi Arabia, E-mail: oussama.bensalha@ isgs.rnu.tn, ousama.bensalha@gmail.com. 


\section{Introduction}

Since the adoption of financial liberalization policies, most developing countries have been exposed to sharp exchange rate fluctuations. This situation has attracted the attention of economists and previous research has been focused on the effects of exchange rate volatility on trade flows (Cho and Corriston 2002, Soleymani and Chua 2014, Karemera et al. 2015, Wong 2017). Previous studies dealing with the effects of exchange rate volatility on economic growth, have often yielded mixed results. This is explained at least by two reasons. First, the effects of exchange rate volatility on the dynamics of growth are contradictory. On the one hand, exchange rate volatility may be considered as a shock absorber and seems to be more appropriate for countries experiencing frequent real shocks; on the other hand, volatility may be associated with higher macroeconomic volatility in terms of international trade, investment, and economic growth. Second, the relationship between exchange rates and economic growth also depends on other control variables such as financial development (Aghion et al. 2009, Ndambendia and AlHayky 2011), and exchange rate regime (Jha 2003).

The purpose of this paper is to shed light on the relationship between exchange rate volatility and economic growth in a sample of 45 developing countries during the period 1985 2015. The empirical investigation takes into account the exchange rate regimes and the financial openness policies.

This paper is structured as follows. Section II reviews the literature that analyzes the transmission mechanisms between exchange rate volatility and economic growth. In Section III, we compute our measure of exchange rate volatility based on the Generalized Autoregressive Conditional Heteroskedasticity (GARCH) model proposed by Bollerslev (1986). The empirical methodology is described in Section IV, and Section V analyzes the empirical results. Section VI concludes. 


\section{Literature Review}

The relationship between exchange rate dynamics and the macroeconomic performance has received considerable attention in previous studies. A few studies have confirmed that exchange rate flexibility acts positively on economic growth through its effect on the adjustment process to shocks (Mundell 1961, Edwards and Levy-Yeyati 2005). Other studies have rather proved the presence of negative effects of exchange rate volatility on some macroeconomic aggregates that may affect economic growth such as international trade, investment, and employment (Doğanlar 2002, Servén 2003, Demir 2010, Belke and Gros 2001).

Since the writings of Friedman (1953) and Mundell (1961, 1963), exchange rate regimes are regarded as a main instrument in the analysis of economic efficiency. Proponents of flexible exchange rate regimes argue that exchange rate variability facilitates the adjustment of economies to asymmetric real shocks (Edwards and Levy-Yeyati 2005). Indeed, when asymmetric real shocks occur and prices and wages are relatively rigid, flexible exchange rates can adjust the relative international prices and, thus, offset production losses (Mundell 1961). In the same vein, Edwards and Levy-Yeyati, (2005) show that exchange rate volatility allows absorbing external shocks by providing greater adaptive capacity while avoiding the persistent and economically expensive adjustment processes. Cerra et al. (2013) and Furceri and Zdzienicka (2011) conclude that during episodes of financial crises, countries with a flexible exchange rate experience lower production losses than fixed exchange rate countries. Another argument in favor of greater exchange rate flexibility/volatility is the monetary policy autonomy and the constraints of credibility and discipline imposed by the exchange rate regime (Mundell 1963, Dornbusch and Giovannini 1990). Indeed, flexible exchange rate regimes allow maintaining an autonomous monetary policy in the presence of strong international capital mobility and, thus, offer the possibility of stabilizing the domestic economy. 
However, the potential benefits of exchange rate flexibility in terms of adjustment to external shocks and monetary policy autonomy should be compared with the cost of unpredictable fluctuations of the local currency. Indeed, an economy with a floating exchange regime could experience unexpected volatility resulting in economic and financial instability and affecting economic growth. Exchange rate volatility can also have indirect effects on economic growth through its impact on the key determinants of the economic activity, such as trade flows, investment, and employment. Regarding this point, several studies have shown that exchange rate variability often leads to a reduction in the volume of international trade (Hooper and Kohlhagen 1978, Pozo 1992). Recently, the development of real options theory allows better analyzing the effects of macroeconomic uncertainty on economic operators' decisions (Dixit and Pindyck 1994). The application of this theory in an open economy has resulted in important research that pays particular attention to the relationship between exchange rate volatility as a factor of uncertainty and the dynamics of investment and employment. Servén $(1997,1998)$ conclude that exchange rate uncertainty justifies waiting and postponement behaviors with regard to investment decisions. Belke and Gros (2001) confirm that exchange rate volatility favors the wait-and-see strategy. By analogy to investment, when making a hiring decision, companies also incur other sunk costs, such as hiring costs and the costs of providing capital to a particular job. Therefore, an increase in exchange rate volatility may discourage firms from creating jobs (Belke and Setzer 2003).

On the empirical side, an abundant studies has confirmed the presence of significant impact of exchange rate volatility on economic growth. Dollar (1992) analyzes the relationship between exchange rate volatility and economic growth in 95 developing countries over the period of 1976 1985 and provides evidence of a negative relationship between the two variables. Bosworth et al. (1995) study the determinants of economic growth in 88 developed and industrial countries during the period of 1960 1992 and conclude that exchange rate volatility negatively affects output growth 
by slowing the factor productivity growth. Schnabl (2009) highlights the negative effect of volatility on economic growth in several European and Asian countries. Similarly, Vieira et al. (2013) confirm the presence of negative effects of exchange rate volatility on long-run economic growth for a sample of 82 developed and emerging countries during the period of 1970 2009. By focusing on the impact of exchange rate volatility on economic growth in 14 Sub-Saharan African countries between 1980 and 1995, Bleaney and Greenaway (2001) show that volatility exerts negative effects on investment but not on economic growth.

Other studies have empirically examined the relationship between exchange rate volatility and the key determinants of economic growth, namely, international trade, investment, and employment. In this context, Vieira and MacDonald (2016) focus on the effects of the real effective exchange rate volatility on export flows in 106 developed and emerging countries between 2000 and 2011 and conclude the existence of a negative link between the two variables. Pino et al. (2016) check the impact of the exchange rate volatility on exports in six Asian economies during the period of 1974 2011. Their empirical investigation reveals that exchange rate volatility has a harmful impact on exports, particularly in the long-run. The second channel through which exchange rate volatility may affect economic growth is investment. Byrne and Davis (2005) provide empirical evidence on the negative response of investment to exchange rates uncertainty in G7 countries. Cavallari and D'Addona (2013) reveal an inverse relationship between exchange rate volatility and foreign direct investment in several OECD countries over the period of 1985 2007. The same conclusion has been reached by SharifiRenani and Mirfatah (2012) for the case of Iran. Kandilov and Leblebicioğlu (2011) conclude that exchange rate volatility exerts a negative impact on manufacturing investment in Colombia. Finally, Demir (2010) and Zmami and Ben-Salha (2015) find a negative effects of exchange rate volatility on employment in Turkish and Tunisian manufacturing firms, respectively. 


\section{Exchange Rate Volatility}

It is important to mention that there is no consensus on an adequate measure of volatility. The first issue refers to the choice of the exchange rate. Existing empirical studies do not offer consensual criteria regarding the use of nominal or real exchange rates. For instance, Servén (2003) computes the volatility of the real exchange rate which depends on the fluctuations of nominal exchange rate and prices. In contrast, according to Vanelle (2001), the nominal exchange rate is preferred because the real exchange rate incorporates price fluctuations, which represents another type of uncertainty for private agents. Finally, some studies suggest that the use of nominal or real exchange rates does not significantly affect the obtained results. In addition, it has been shown that real and nominal exchange rates have evolved in a highly correlated fashion in the presence of floating exchange rate regimes, which explains the non-sensitivity of results regarding the used exchange rate proxy.

The second issue is related to the choice of the volatility measure (Dell'Ariccia 1999). The presence of multiple measures of volatility partly explains the ambiguous effects of exchange rate volatility on economic growth. Most empirical studies on the subject essentially make use of two measures. The first measure is based on the historical volatility and focuses on dispersion indicators such as the standard deviation and the coefficient of variation (Kenen and Rodrick 1986, Dell'Ariccia 1999). However, historical volatility does not take into account the exchange rate uncertainty, which represents the unforeseen share of exchange rate fluctuations. It would be better, therefore, to use the concept of conditional volatility as measured by the GARCH model developed by Bollerslev (1986). Table A1 in the Appendix summarizes the exchange rate volatility measures and their impact on macroeconomic performance in previous studies. It is worth noting that most studies employ conditional volatility measures. Moreover, some show that exchange rate time series do not exhibit Gaussian behavior (Atlan et al. 1992) and thus, criticize the use of the standard deviation and the coefficient of variation.

The current paper measures exchange rate volatility based on the GARCH 
conditional variance using the following two equations:

$$
\begin{gathered}
\text { ex } x_{t}=\beta_{0}+\sum_{i=1}^{p} \beta_{i} e x_{t-i}+\varepsilon_{t} \\
h_{m t}=\sigma_{m t}^{2}=\lambda_{0}+\sum_{i=1}^{p} \lambda_{0} \varepsilon_{t-1}^{2}+\sum_{i=1}^{p} \mu_{0} \sigma_{t-i}^{2}
\end{gathered}
$$

where $e x_{t}$ and $h_{m t}$ denote the logarithm of nominal and real exchange rates and the conditional variance, respectively. The latter represents our monthly exchange rate volatility. The construction of the monthly exchange rate volatility indices using the GARCH $(1,1)$ model is based on the estimation of Equations (1) and (2). The empirical analysis is carried out for 45 developing economies during the period 1985 $2015^{1}$. Monthly real and nominal effective exchange rates are extracted from the International Financial Statistics database of the International Monetary Fund. By estimating Equations (1) and (2) for each country, we obtain monthly exchange rate volatility time series. Figures 1 and 2 plot the evolution of monthly nominal and real exchange rate volatility by country $\left(h_{m t}\right)$.

Finally, we compute the annual exchange rate volatility as follows:

$$
\operatorname{vex}_{t}=\frac{1}{12} \times\left(h_{m 1}+h_{m 2}+\ldots \ldots+h_{m 12}\right)
$$

\section{Empirical Methodology}

To estimate the effects of exchange rate volatility on economic growth, the following model is used:

$$
y_{i t}=\alpha+\beta y_{i t-1}+\varphi v e x_{i t}+\delta^{\prime} X_{i t}+\mu_{i}+\lambda_{t}+\varepsilon_{i t}
$$

${ }^{1}$ The choice of countries included in the empirical analysis is dictated by the availability of data on monthly effective exchange rates in the International Financial Statistics. All emerging and developing countries having data during the period of the study have been selected. The sample is reported in Table A2 in the Appendix. 
where $y_{i t}$ represents the logarithm of real per capita GDP, $y_{i t-1}$ indicates the lagged logarithm of real per capita GDP, and vex the conditional exchange rates volatility. $X_{i t}$ is a matrix of control variables and $\mu_{i}, \lambda_{t}$, and $\varepsilon_{t}$ are the country-specific effects, the time specific effect, and the error term, respectively. $i$ and $t$ denote country and year, respectively.

Figure 1. Nominal effective exchange rate volatility

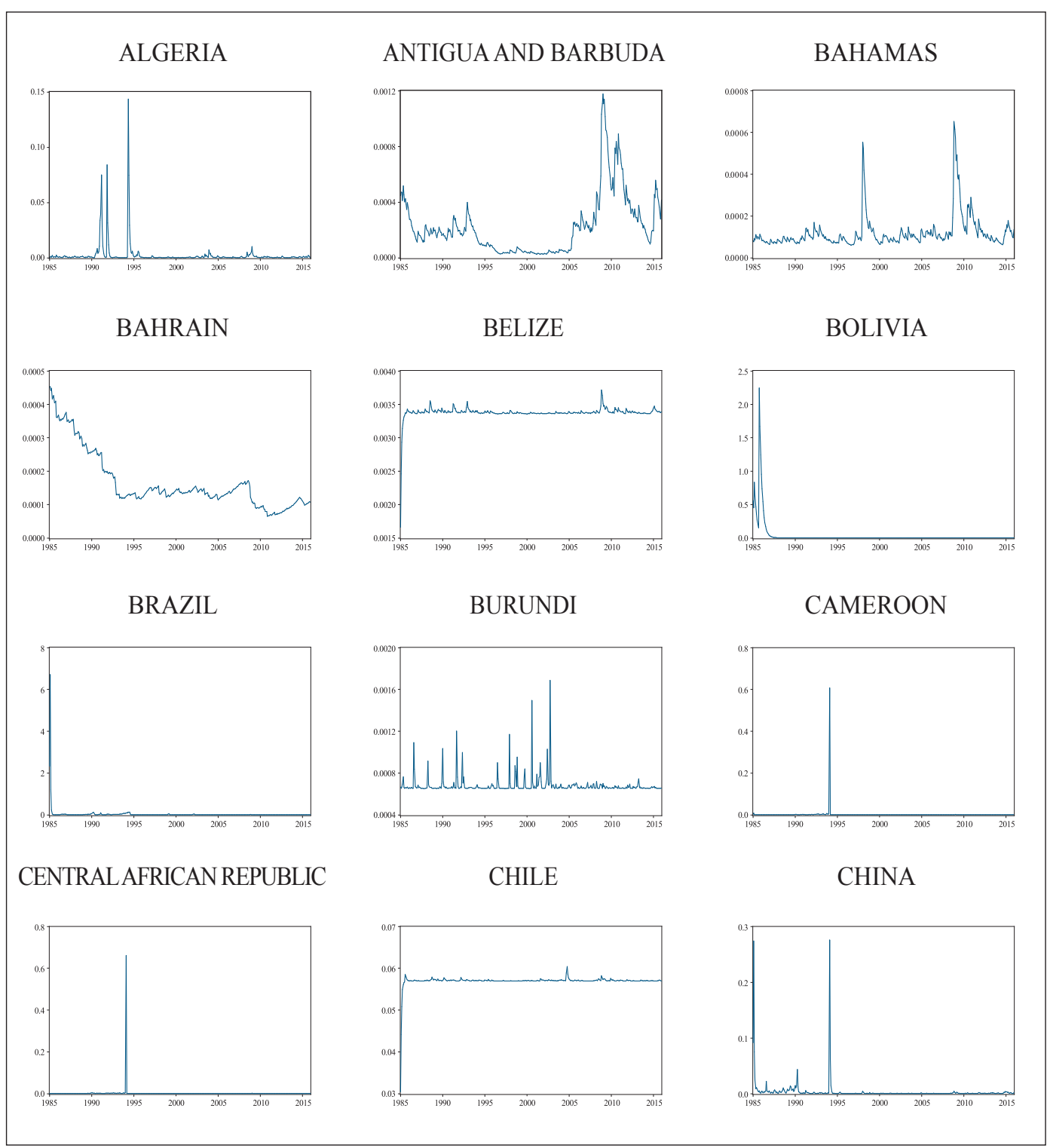


(continued)
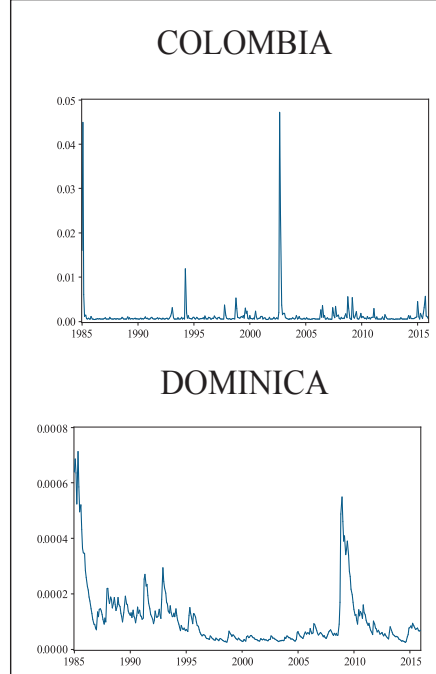

FIJI

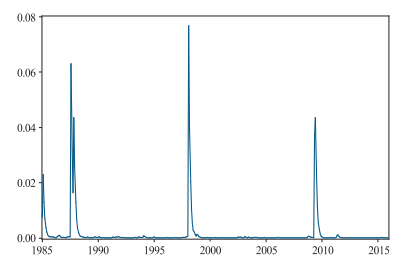

GHANA

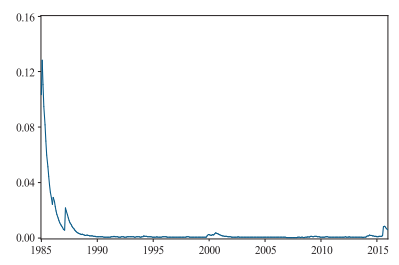

IRAN

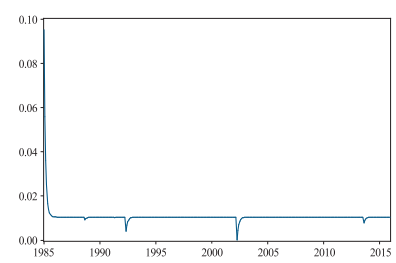

MALAYSIA

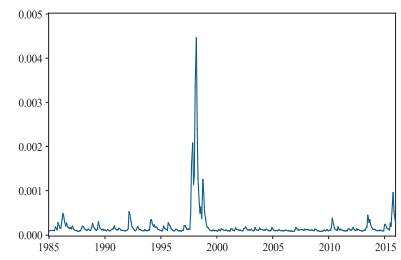

COTRA RICA

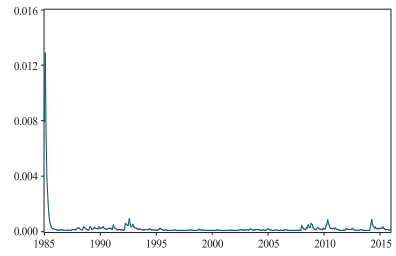

DOMINICAN REPUBLIC

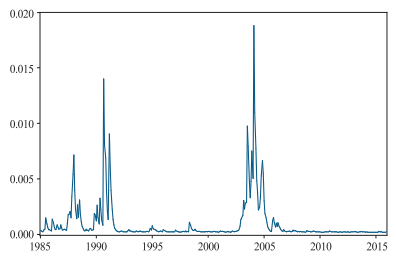

GABON

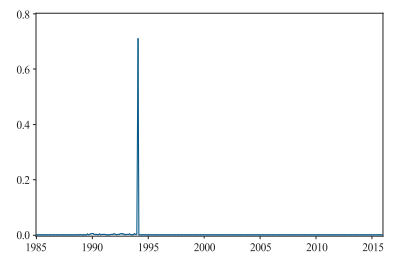

GRENADA

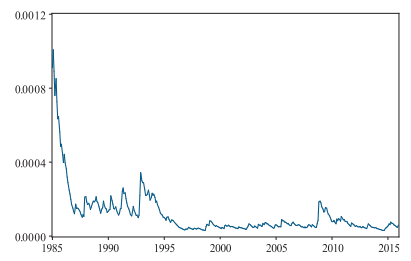

LESOTHO

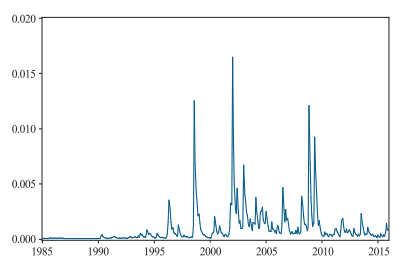

MEXICO

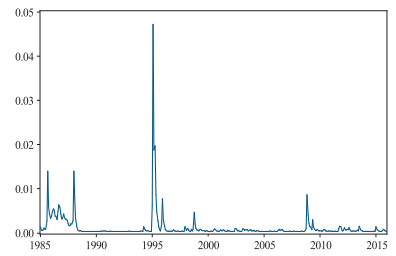

COTE D'IVOIRE

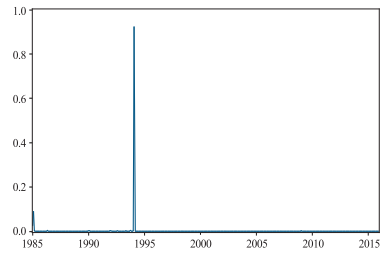

EQUATORIAL GUINEA

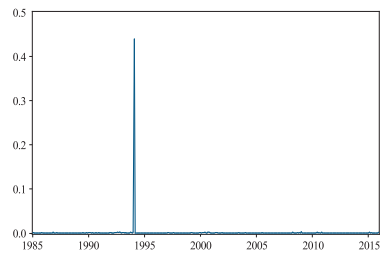

GAMBIA

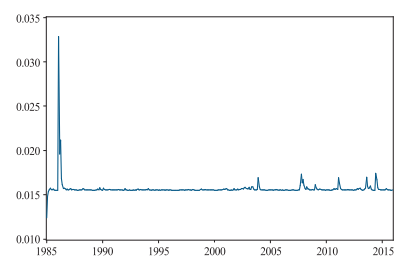

GUYANA

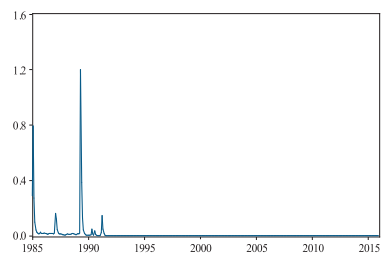

MALAWI

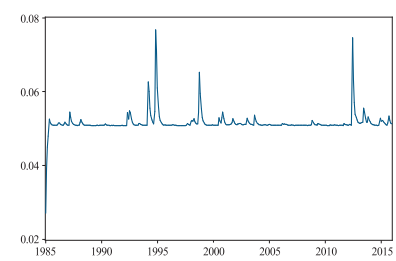

NICARAGUA

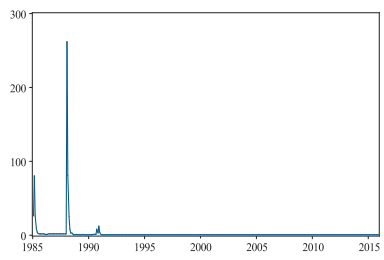


(continued)

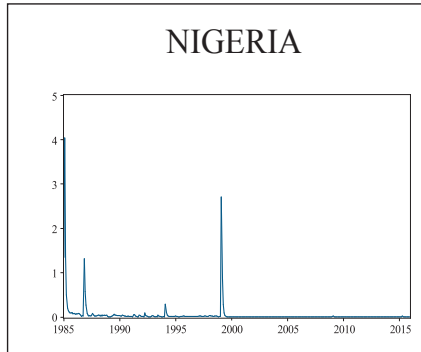

PARAGUAY

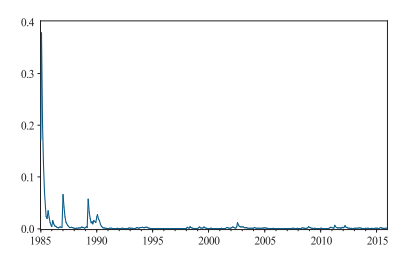

SIERRA LEONE

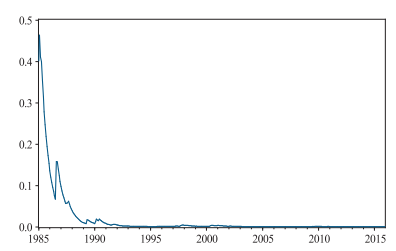

TOGO

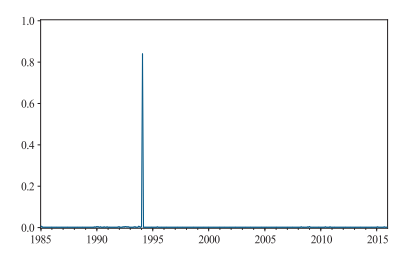

UGANDA

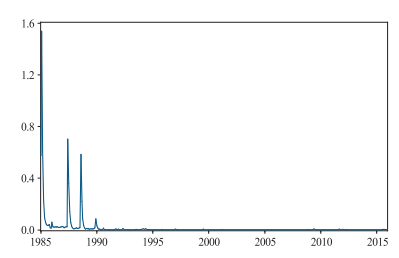

PAKISTAN

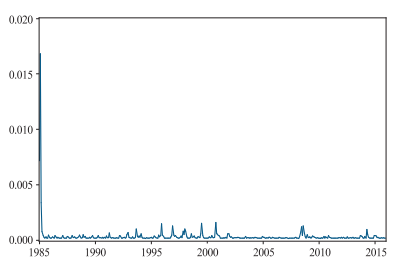

PHILIPPINES

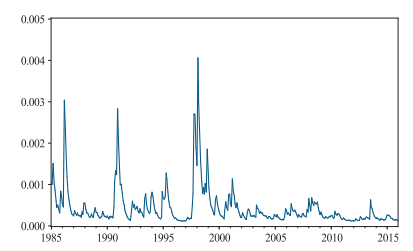

SINGAPORE

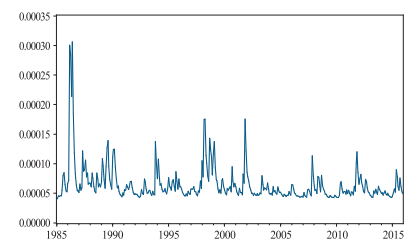

TRINIDAD AND TOBAGO

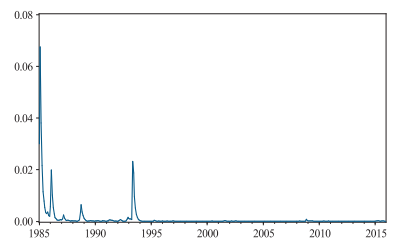

URUGUAY

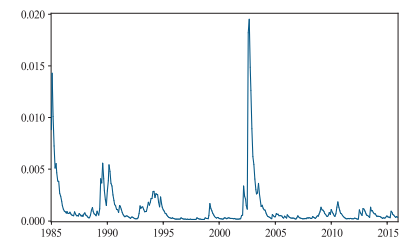

PAPUA NEW GUINEA

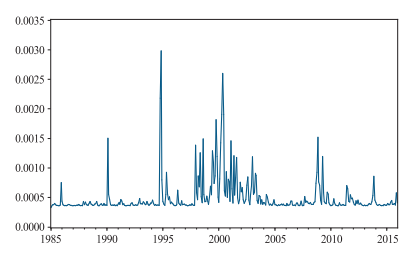

SAUDI ARABIA

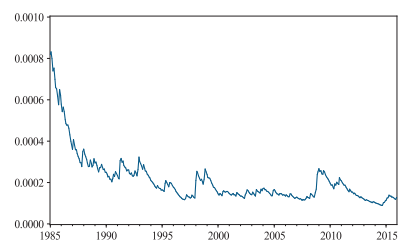

SOUTH AFRICA

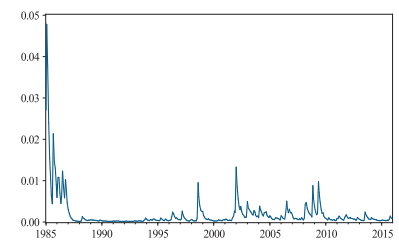

TUNISIA

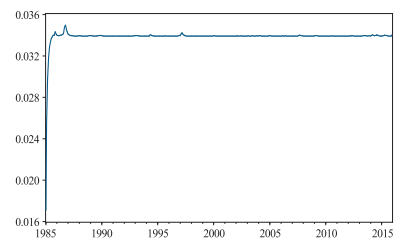

VENEZUELA

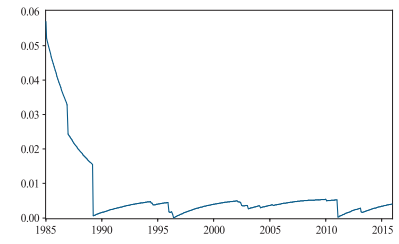


Figure 2. Real effective exchange rate volatility

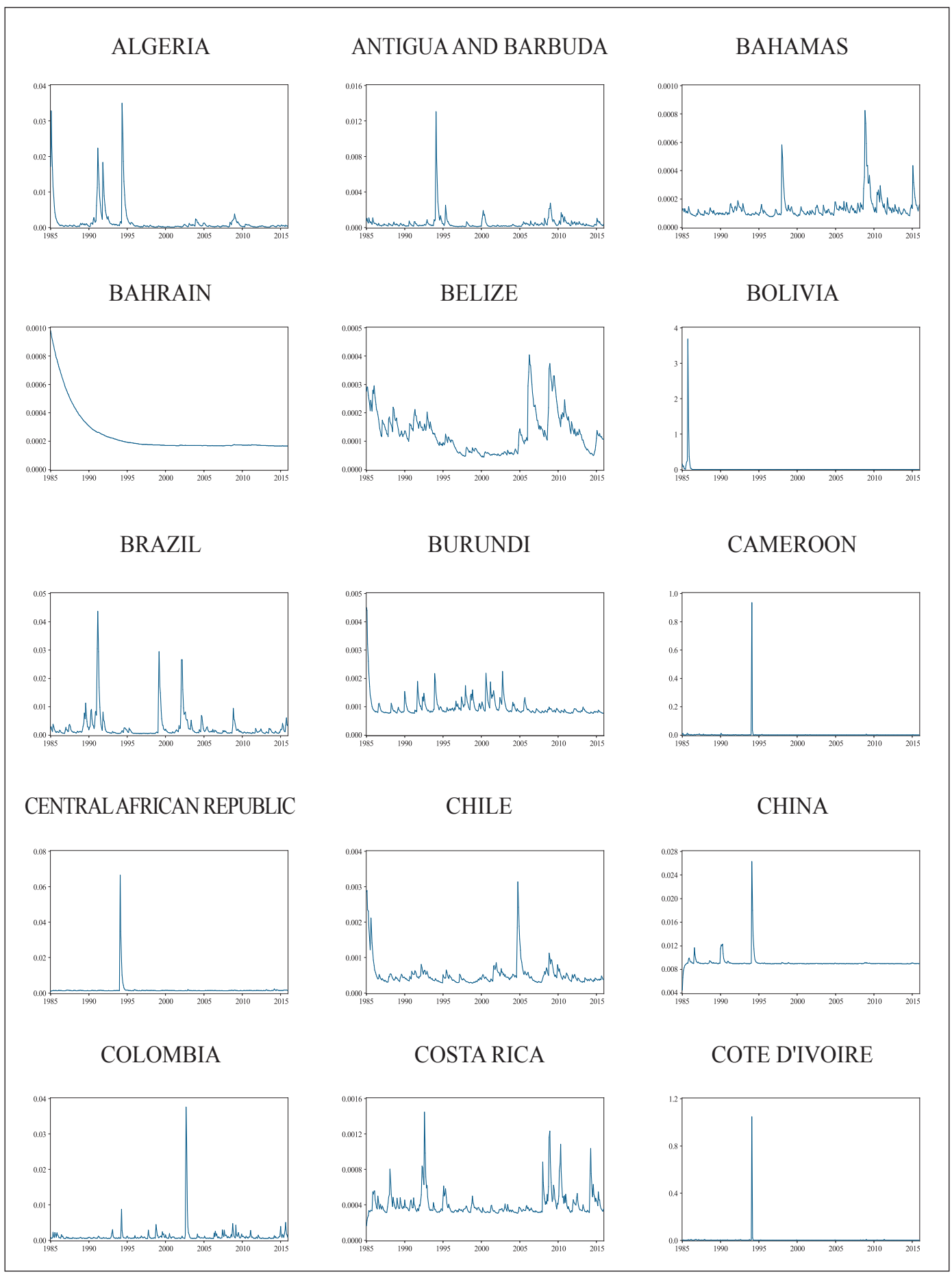


(continued)

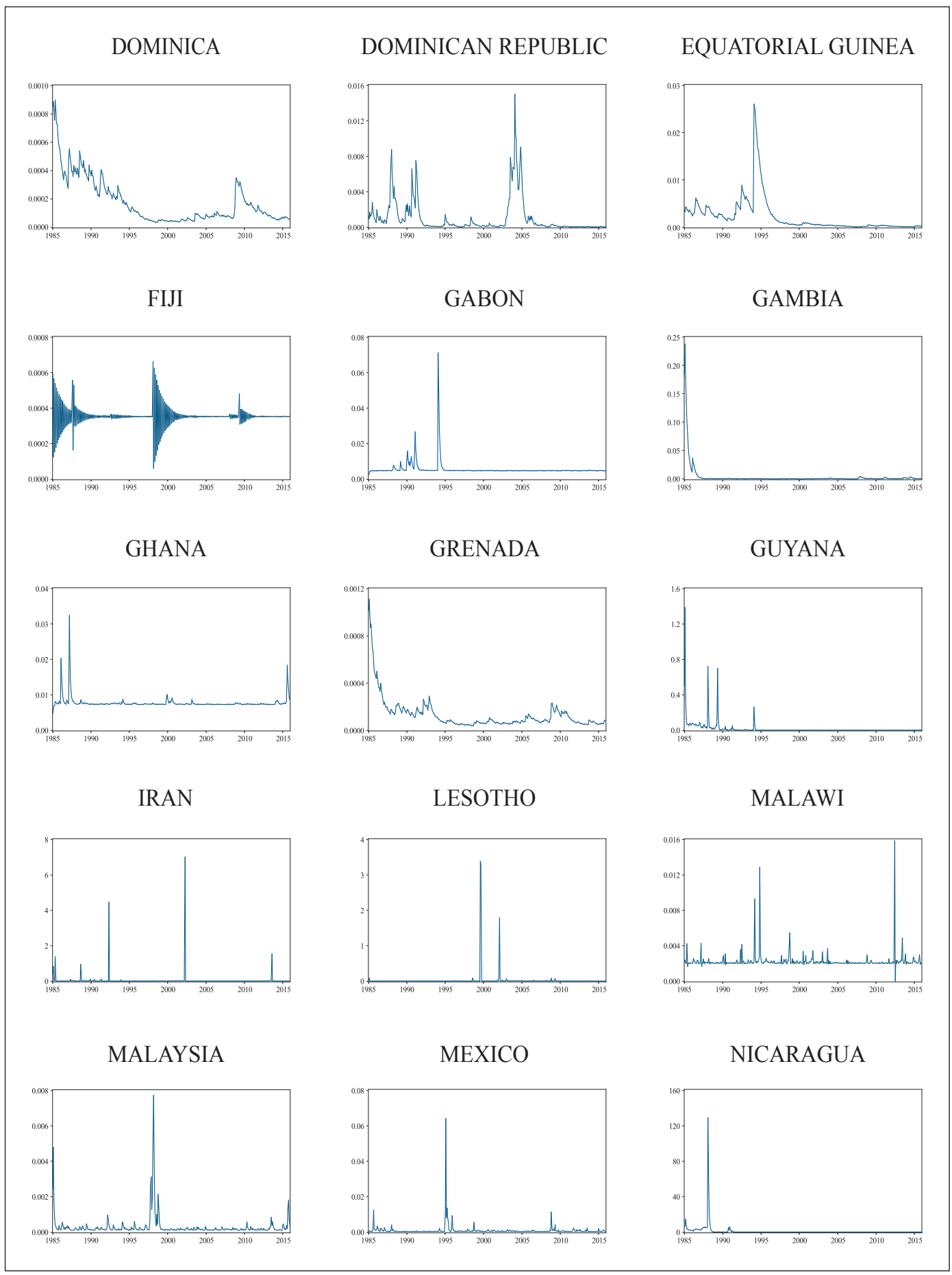


(continued)

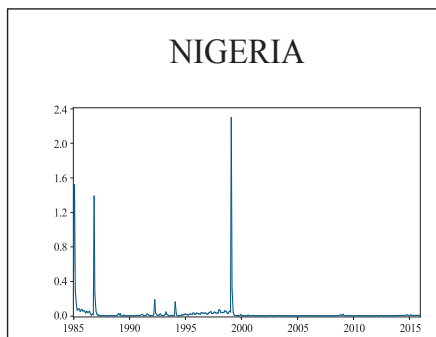

PARAGUAY

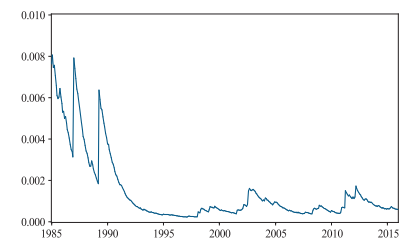

SIERRA LEONE

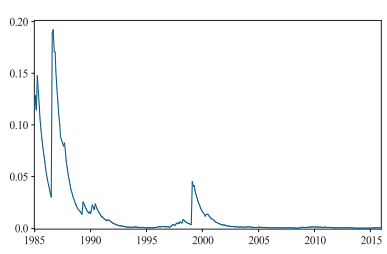

TOGO

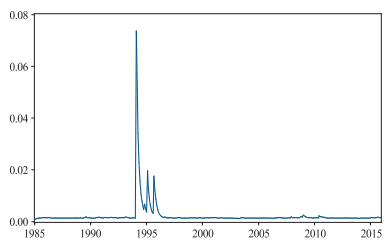

UGANDA

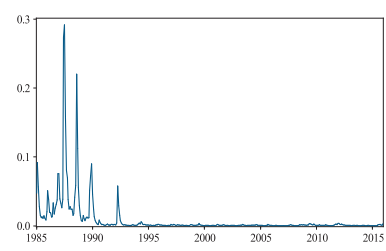

PAKISTAN

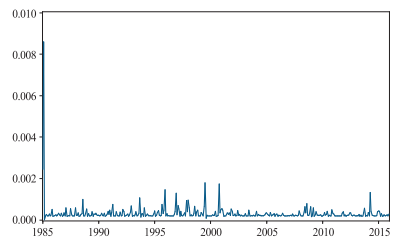

PHILIPPINES

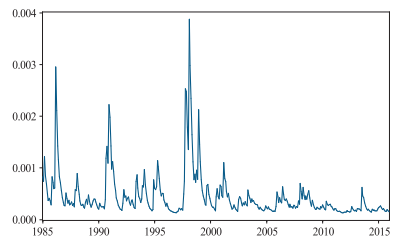

SINGAPORE

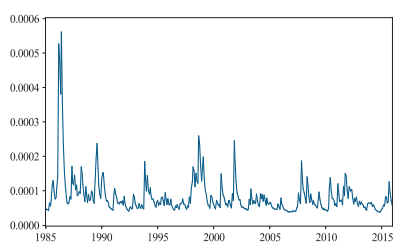

TRINIDAD AND TOBAGO

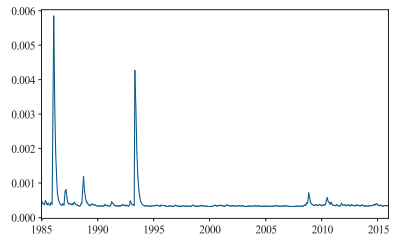

URUGUAY

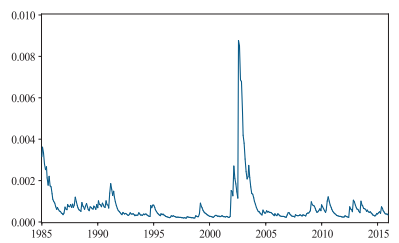

PAPUA NEW GUINEA

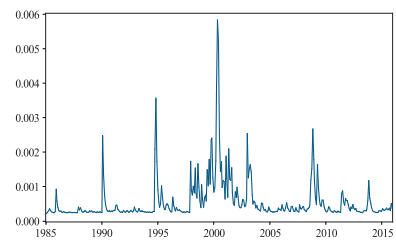

SAUDI ARABIA

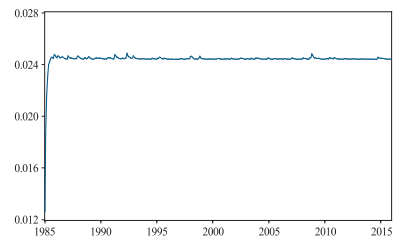

SOUTH AFRICA

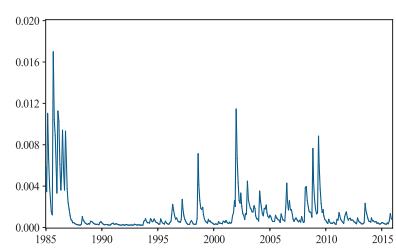

TUNISIA

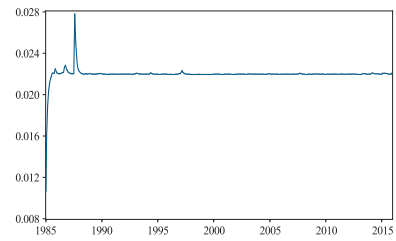

VENEZUELA

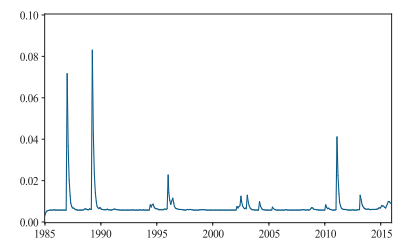


The nominal and real exchange rate volatility represents the interest variable. As outlined earlier, volatility is measured by the conditional variance of exchange rates obtained by fitting the GARCH $(1,1)$ model. Regarding the control variable, we introduce the population growth rate (an increase of the population reduces the per capita GDP and, thus, the associated coefficient is expected to be negative), the logarithm of trade openness, proxied by the sum of exports and imports divided by GDP (trade openness can promote growth by promoting specialization and facilitating imports of technological and capital goods and, thus, the associated coefficient is expected to be positive), and, finally, the logarithm of the public expenditure, proxied by the government spending as a percentage of GDP. The impact of this variable on economic growth is ambiguous. On the one hand, an increase in public spending is likely to have a negative effect on growth through crowding-out effects on private investment. On the other hand, an increase in public spending may improve infrastructure and positively affect economic growth. The associated coefficient may be positive or negative. As mentioned earlier, the analysis considers a sample of 45 emerging and developing countries. Data on the dependent and the control variables come from the World Development Indicators database of the World Bank.

Given the existence of the lagged dependent variable among the righthand variables due to the presence of adjustment process, a dynamic panel data model is preferred. In line with the previous empirical growth studies, the Generalized Method of Moments (GMM) estimator is implemented in this paper. We particularly use the difference GMM estimator developed by Arellano and Bond (1991) and the system GMM estimator developed by Blundel and Bond (1998). Although the difference GMM estimator provides more efficient estimators than standard techniques, it has some drawbacks for small samples, which motivated Blundell and Bond (1998) to propose the system GMM. The consistency of the GMM estimator may be checked through the Sargan-Hansen test of over-identifying restrictions and the second-order autocorrelation in the first-differenced errors. 


\section{Empirical Results}

\section{A. The full sample}

We estimate Equation (4) using two techniques, the system GMM and the difference GMM. Table 1 presents the results of the full sample of countries.

Table 1. Exchange rate volatility and economic growth

(full sample)

\begin{tabular}{|l|c|c|c|c|}
\hline \multirow{2}{*}{ Lagged per capita GDP } & \multicolumn{2}{|c|}{ System GMM } & \multicolumn{2}{c|}{ Difference GMM } \\
\cline { 2 - 5 } & $(1)$ & $(2)$ & $(3)$ & $(4)$ \\
\hline Population & $0.966^{* * *}$ & $0.966^{* * *}$ & $0.961^{* * *}$ & $0.961^{* * *}$ \\
& $(0.014)$ & $(0.014)$ & $(0.017)$ & $(0.017)$ \\
\hline Government consumption/GDP & -0.005 & -0.005 & $-0.010^{* * *}$ & $-0.010^{* * *}$ \\
& $(0.007)$ & $(0.007)$ & $(0.004)$ & $(0.004)$ \\
\hline Trade openness & $-0.037^{*}$ & $-0.036^{*}$ & $-0.079^{* *}$ & $-0.078^{* *}$ \\
& $0.021)$ & $(0.021)$ & $(0.036)$ & $(0.036)$ \\
\hline Nominal effective exchange & $-0.137 * * *$ & $0.137 * * *$ & $0.085^{*}$ & $0.083^{*}$ \\
rate volatility & $(0.031)$ & $(0.032)$ & $(0.043)$ & $(0.043)$ \\
\hline Real effective exchange rate & $(0.0003)$ & - & $-0.004^{* * *}$ & - \\
volatility & - & $-0.008^{* * *}$ & - & $-0.008^{* * *}$ \\
\hline Serial correlation test $(p$-value) & & $(0.0007)$ & & $(0.0007)$ \\
\hline \multicolumn{1}{|c|}{ First-order } & 0.001 & 0.001 & 0.000 & 0.000 \\
\hline Second-order & 0.271 & 0.265 & 0.211 & 0.206 \\
\hline Hansen $J$ test $(p$-value) & 0.636 & 0.624 & 0.827 & 0.826 \\
\hline Number of countries & 45 & 45 & 45 & 45 \\
\hline
\end{tabular}

(Note) Dependent variable: per capita GDP. All estimates are performed using the xtabond2 command developed by Roodman (2009). Coefficients and robust standard errors in parentheses are obtained using the two-step GMM and the Windmeijer (2005) finite-sample correction. The null hypothesis for the Hansen $J$ test is that the instruments are not correlated with the residuals while the null hypothesis for the serial correlation test is that the errors in the first difference regression exhibit a first-order serial correlation and no second-order serial correlation. ***,**, and * represent statistical significance at $1 \%, 5 \%$, and $10 \%$, respectively. 
Regardless whether the system or difference GMM estimator is used, coefficients associated with the lagged dependent variable are significant in all specifications, confirming the existence of adjustment process and the appropriateness of implementing a dynamic panel modeling. Furthermore, the table shows that the $p$-values associated with the Hansen test of overidentifying restrictions and the second-order autocorrelation test are greater than 5\%. This implies that we cannot reject the null hypotheses of the validity of the instruments used and the absence of second-order autocorrelation of the residuals. Regarding the control variables, results show that the associated coefficients are significant. Indeed, the population growth rate exerts a negative and significant impact on economic growth. The coefficients associated with trade openness are positive and significant, which supports previous empirical evidence confirming the existence of a positive correlation between the two variables (Sach and Warner 1995, Edwards 1998, Frankel and Romer 1999). Public expenditure coefficients are negative in all specifications, reflecting the fact that such expenditures have adverse effects on economic growth in developing countries. Regarding our interest variable, findings suggest that exchange rate volatility exerts negative effects on economic growth. Such findings are robust because they hold valid when the system or difference GMM estimator is used. In addition, the impact of real exchange rate volatility on economic growth is higher than the one exerted by nominal exchange rate volatility. By reference to theoretical predictions, the negative effect of exchange rate volatility on economic growth may be explained through its effects of uncertainty and instability. Such negative effects are greater than the positive effect of volatility through the adjustment of the economy to potential shocks. 


\section{B. Exchange rate regime and financial openness}

The aim of this section is to check if the impact of exchange rate volatility on economic growth depends upon the exchange rate regime and the degree of financial openness. The decomposition of the full sample is made based on the two aforementioned criteria ${ }^{2}$. To account for the role of the exchange rate regime, we consider two sub-samples of countries. The classification is based on the Annual Report on Exchange Arrangements and Exchange Restrictions published by the International Monetary Fund (2014). While the report considers eight exchange rate regimes, we use the classification to construct two broad categories of exchange rate regimes, namely, fixed and relatively flexible regimes. The first sample comprises countries that adopt fixed exchange rate regimes and includes 16 countries while the second sample comprises countries that adopt relatively flexible regimes (Stabilized Arrangement, Crawling Peg, Other Managed Arranging Floating, and Free Floating) and includes 29 countries. To avoid overloading the presentation, we only present in Table 2 the coefficients associated with the exchange rate volatility for the two sub-samples and using the system and difference GMM.

${ }^{2}$ Classification of the full sample according to these two criteria is reported in Table A2 in the Appendix. 


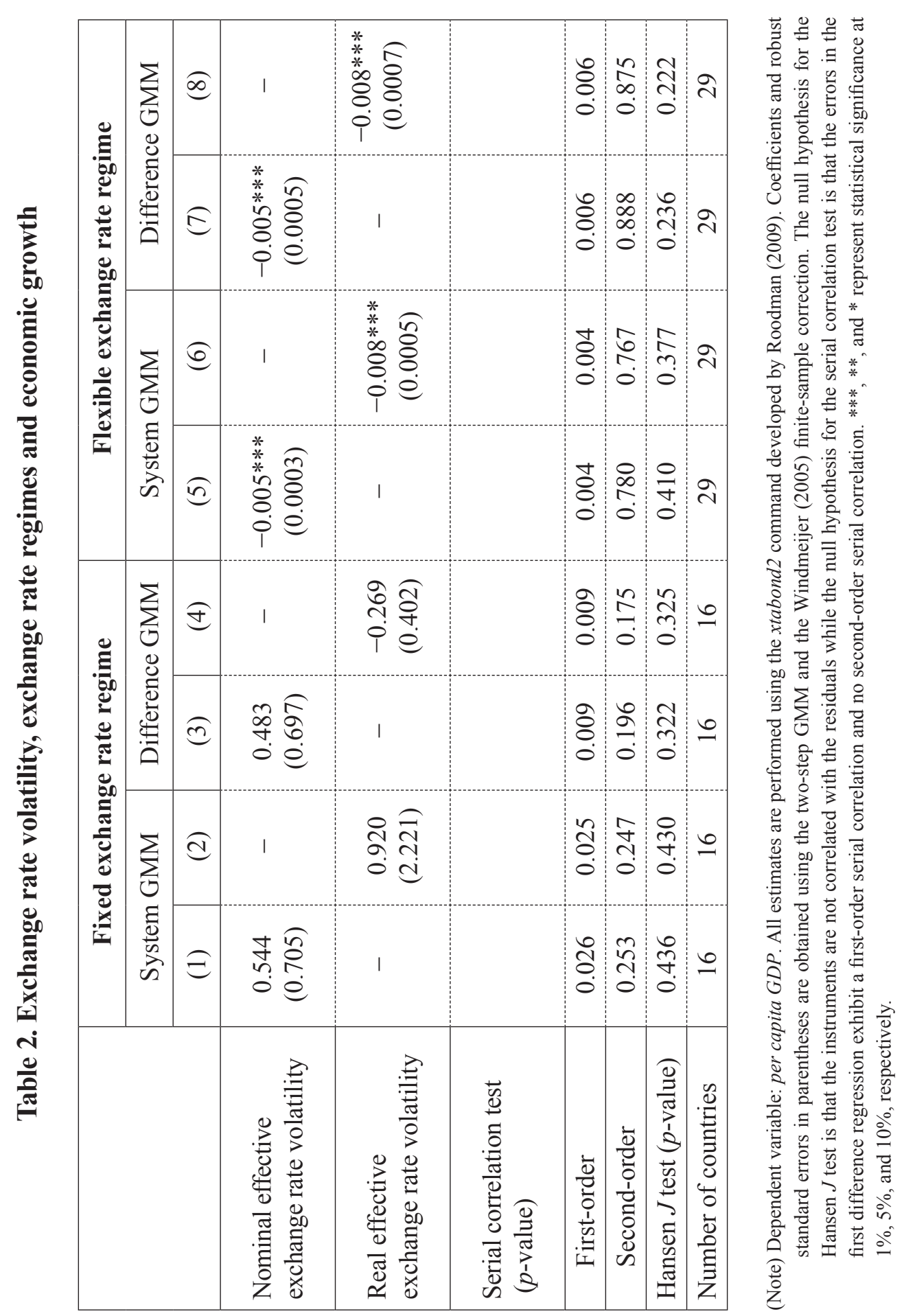


Looking at the various exchange rate volatility estimates, we find that coefficients of the exchange rate are always negative and statistically significant only in countries that adopt relatively flexible exchange rate regimes. To explain such findings, we report in Table 3 some descriptive statistics on nominal and real exchange rate volatility in the two groups of countries.

Table 3. Descriptive statistics

\begin{tabular}{|l|c|c|c|}
\hline \multirow{2}{*}{ All countries } & \multicolumn{2}{|c|}{ Exchange rate regime } \\
\cline { 2 - 4 } & & Fixed & Flexible \\
\hline Nominal exchange rate volatility & \multicolumn{2}{|l}{} \\
\hline Maximum & 32.096 & 0.077 & 32.096 \\
\hline Minimum & 0.000014 & 0.000014 & 0.00002 \\
\hline Mean & 0.045 & 0.001 & 0.060 \\
\hline Real exchange rate volatility \\
\hline Maximum & 18.706 & 0.558 & 18.706 \\
\hline Minimum & 0.000041 & 0.000041 & 0.000047 \\
\hline Mean & 0.029 & 0.004 & 0.042 \\
\hline
\end{tabular}

As shown in Table 3, the average nominal and real exchange rate volatilities are about 0.045 and 0.029 , respectively, for the full sample of countries. Volatility is found to be higher in countries with flexible exchange rate regimes than in countries with fixed regimes. The mean nominal exchange rate volatility is about $0.1 \%$ for fixed exchange rate countries and $6 \%$ for countries with flexible exchange rate regimes. On the other hand, the mean real exchange rate volatility is equal to $0.4 \%$ in countries with fixed exchange rate regimes and $4.2 \%$ for countries with flexible exchange rate regimes. These statistics provide important arguments explaining the significance and magnitude of coefficients associated with nominal and 
real exchange rate volatility. The negative effects of volatility on economic growth are, therefore, widespread in countries with flexible exchange rate regimes, thus penalizing international trade and investment operations and, hence, economic growth. On the other hand, exchange rate volatility is relatively low in fixed exchange rate regimes and, consequently, without macroeconomic impact on the considered sample. It is therefore reasonable that no significant link between exchange rate volatility and economic growth is detected in countries adopting fixed exchange rate regimes. These results are in line with some prior studies that examined the suitability of fixed exchange rate systems in boosting economic growth. For instance, Dubas et al. (2005) conclude that developing countries with de facto fixed exchange rate regimes show relatively quicker economic growth.

The second decomposition is based on the degree of financial openness. To do this, two sub-samples are considered. We particularly focus on external financial liberalization, which consists of eliminating restrictions on crossborder financial transactions. The classification is based on the KAOPEN index developed by Chinn and Ito (2008) to measure the intensity of capital account restrictions. As in Kose et al. (2009), economies having a degree of financial openness above the median are considered as more financially open economies (22) while those with below-median levels are considered as less financially open economies (23). The results are displayed in Table 4. 


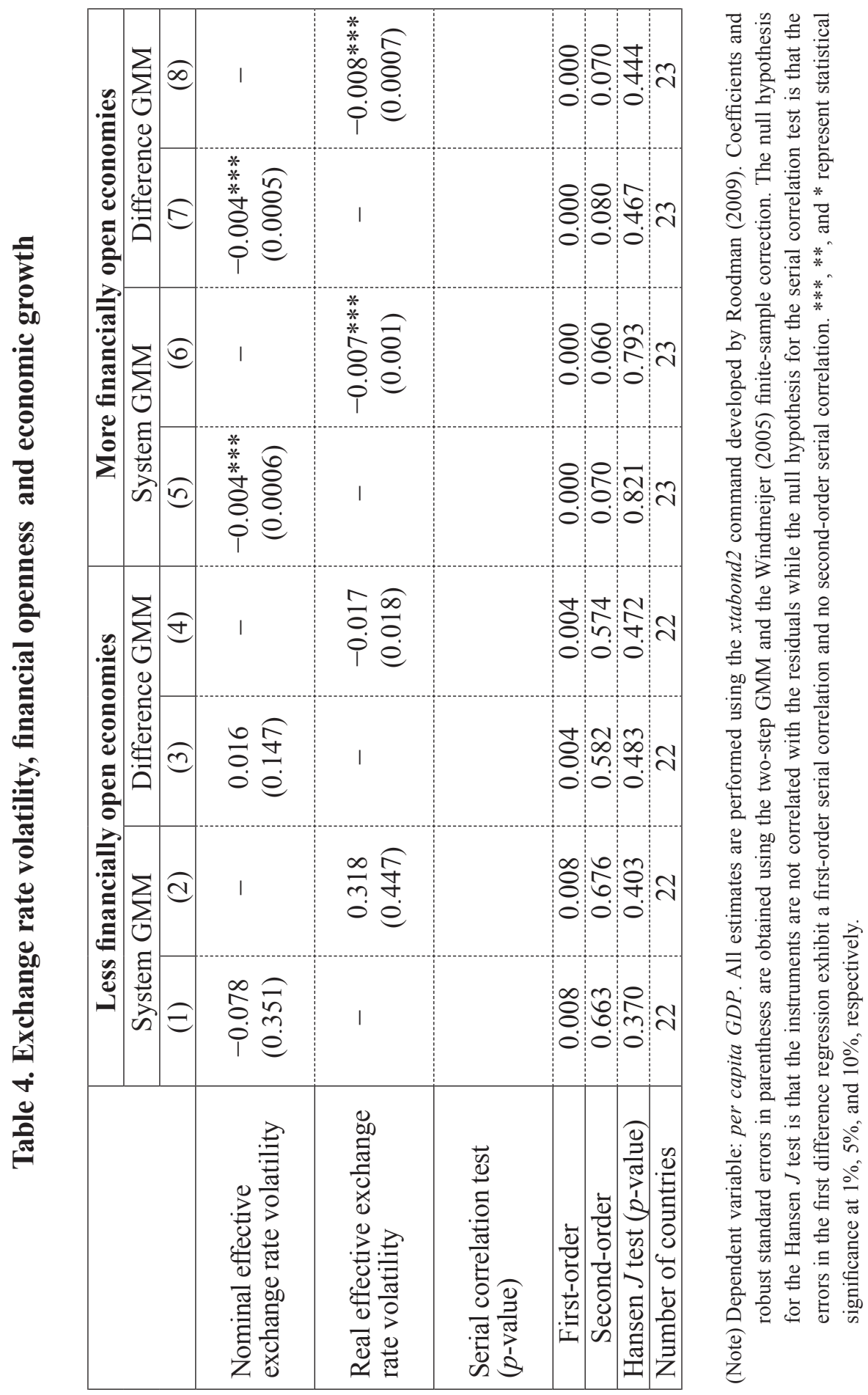


The econometric analysis shows that coefficients of nominal and real exchange rate volatility are statistically significantly only in financially liberalized economies. Free capital movement contributes to a considerable increase in exchange rate volatility and, thus, negatively affects economic growth.

\section{Conclusion}

This paper examines the impact of exchange rate volatility on the dynamics of economic growth in developing countries. It particularly checks the role of exchange rate regimes and the degree of financial openness in explaining the impact of exchange rate volatility on economic growth. The empirical investigation is based on a sample of 45 developing countries during the period 1985 2015. On the empirical level, the nominal and real exchange rate volatilities are measured using the GARCH $(1,1)$ model. Different estimations are carried out by using the difference and system GMM estimators. The empirical results can be summarized in three main points. First, nominal and real exchange rate volatilities have negative and statistically significant effects on economic growth. Second, the effects of volatility are negative in countries with flexible exchange rate regimes, whereas they are not significant in countries with fixed regimes. In economies with flexible exchange rate regimes, exchange volatility is relatively high. Economic operators acting in such a macroeconomic environment might fear from the uncertainty related to the evolution of future exchange rates and prefer to postpone their trade and investment operations, which may be harmful for economic growth. In countries with fixed exchange rates, uncertainty of exchange rate evolution is relatively limited and, consequently, these fluctuations have no impact on their economic performance. Finally, our empirical analysis considers the role of financial openness in explaining the relationship between exchange 
volatility and economic growth. It concludes that the impact of exchange rate volatility on economic growth is negative and more pronounced in financially open economies. These results have important implications for the design of exchange rate policies in developing countries. Given the importance of international trade and investment in the process of economic growth, these countries must try to follow an exchange rate policy that principally seeks to stabilize exchange rates. A relatively stable and predictable exchange rate seems to be fundamental to enhance economic growth.

Received 6 February 2018, Revised 28 April 2018, Acccepted 9 May 2018

\section{References}

Aghion, P., Bacchetta, P., Ranciere, R. and Rogoff, K. "Exchange rate volatility and productivity growth: the role of financial development,"Journal of Monetary Economics 56 (2009): 494-513.

Arellano, M. and Bond, S. "Some tests of specification for panel data: Monte Carlo evidence and an application to employment equations," Review of Economic Studies 58 (1991): 277-297.

Arratibel, O., Furceri, D., Martin, R. and Zdzienicka, A. "The effect of nominal exchange rate volatility on real macroeconomic performance in the CEE Countries," Economic Systems 35 (2011): 261-277.

Atlan F., Avouyi-Dovi S. and Ducos P. "Dynamique des taux de change: propriétés statistiques des taux de change," in Finance Internationale : L'État actuel de la Théorie, edited by Girardin, E., Economica, 1992. 
Bahmani-Oskooee, M. and Hajilee, M. "Exchange rate volatility and its impact on domestic investment," Research in Economics 67 (2013): 1-12.

Belke, A.H. Kaas, L. and Setzer, R. "Exchange rate volatility and labor markets in the CEE countries," CEPR Discussion Paper No. 4802 (2004).

Belke, A.H. and Gros, D. "Real impacts of intra-European exchange rate variability: A case for EMU?" Open Economies Review 12 (2001): 231-264.

Belke, A.H. and Setzer, R. "Exchange rate variability and labor Market performance in the Visegrad Countries," Economics of Planning 36 (2003): 153-175.

Bhandari, R. and Upadhyaya, K.P. "Panel data evidence of the impact of exchange rate uncertainty on private investment in South-east Asia," Applied Economics 42 (2010): 57-61.

Bleaney, M. and Greenaway, D. "The impact of terms of trade and real exchange rate volatility on investment and growth in Sub-Saharan Africa," Journal of Development Economics 65 (2001): 491-500.

Blundell, R. and Bond, S. "Initial conditions and moment restrictions in dynamic panel data models," Journal of Econometrics 87 (1998): 1115-1143.

Bollerslev T. "Generalized Autregressive Conditional Heteroskedasticity,"Journal of Econometrics 31 (1986): 307-327.

Bosworth, B.P., Collins, S.M. and Chen, Y.C. "Accounting for differences in economic growth," in Structural Adjustment and Economic Reform: East Asia, Latin America, and Central and Eastern Europe, edited by Kohsaka, A. and Ohno, K. Institute of Developing Economies: Tokyo (1995). 
Byrne, J.P. and Davis, E.P. "Investment and uncertainty in the G7," Review of World Economics 141 (2005): 1-32.

Cavallari, L. and d'Addona, S. "Nominal and real volatility as determinants of FDI," Applied Economics 45 (2013): 2603-2610.

Cerra V., Panizza, U. and Saxena, S. "International evidence on recovery from recessions," Contemporary Economic Policy 31 (2013): 424-439.

Chinn, M.D. and Ito, H. "A new measure of financial openness," Journal of Comparative Policy Analysis 10 (2008): 309-322.

Cho, G., Sheldon, I. and McCorriston S. "Exchange rate uncertainty and agricultural trade," American Journal of Agricultural Economics 84 (2002): 931-942.

Chowdhury, A.R. and Wheeler, M. "The impact of output and exchange rate volatility on fixed private investment: evidence from selected G7 countries," Applied Economics 47 (2015): 2628-2641.

Dell'Ariccia, G. "Exchange rate fluctuations and trade flows: Evidence from the European Union," IMF Staff Papers 46 (1999): 315-334.

Demir, F. "Exchange rate volatility and employment growth in developing countries: evidence from Turkey," World Development 38 (2010): 1127-1140.

Dixit, R.K. and Pindyck R.S. Investment under uncertainty. Princeton: Princeton University Press, 1994.

Doğanlar, M. "Estimating the impact of exchange rate volatility on exports: Evidence from Asian countries," Applied Economics Letters 9 (2002): 859863. 
Dollar, D. "Outward-oriented developing economies really do grow more rapidly: Evidence from 95 LDCs, 1976-1985," Economic Development and Cultural Change 40 (1992): 523-544.

Dornbusch R. and Giovannini, A. "Monetary policy in the open economy," in Handbook of Monetary Economics, edited by Friedman M. and Woodford, M. Elsevier, 1990.

Dubas J.M., Lee, B.J. and Mark, N.C. "Effective exchange rate classifications and growth," NBER Working Paper No. 11272 (2005).

Edwards, S. "Openness, productivity and growth: What do we really know?" The Economic Journal 108 (1998): 383-398.

Edwards, S. and Levy-Yeyati, E. "Flexible exchange rates as shock absorbers," European Economic Review 49 (2005): 2079-2105.

Feldmann, H. "The unemployment effect of exchange rate volatility in industrial countries," Economics Letters 111 (2011): 268-271.

Frankel, J. and Romer, D. "Does trade cause growth?" American Economic Review 89 (1999): 379-399.

Friedman, M. "The methodology of positive economics," in Essays in Positive Economics, edited by Friedman, M. Chicago: University of Chicago Press, 1953.

Furceri, D. and Zdzienicka, A. "The real effect of financial crises in the European transition economies." Economics of Transition 19 (2011): 1-25.

Hooper, P. and Kohlhagen, S.W. "The effect of exchange rate uncertainty on the prices and volume of international trade," Journal of International Economics 8 (1978): 483-511. 
International Monetary Fund. Annual Report on Exchange Arrangements and Exchange Restrictions. Washington DC: IMF, 2014.

Jha, R. Macroeconomics for developing countries, Second Edition. London: Routledge, 2003.

Karemera, D., Koo, W., Smalls, G. and Whiteside, L. "Trade creation, diversion effects and exchange rate volatility in the global meat trade,"Journal of Economic Integration 30 (2015): 240-268.

Kandilov, I.T. and Leblebicioglu, A. "The impact of exchange rate volatility on plant-level investment: Evidence from Colombia," Journal of Development Economics 94 (2011): 220-230.

Katusiime, L., Agbola, F.W. and Shamsuddin, A. "Exchange rate volatilityeconomic growth nexus in Uganda," Applied Economics 48 (2015): 24282442.

Kenen, P.B. and Rodrik, D. "Measuring and analyzing the effects of shortterm volatility in real exchange rates," The Review of Economics and Statistics 68 (1986): 311-315.

Kočenda, E., Maurel, M. and Schnabl, G. "Short- and long-term growth effects of exchange rate adjustment," Review of International Economics 21 (2013): 137-150.

Mundell R.A. "Capital mobility and stabilization policy under fixed and flexible exchange rates," The Canadian Journal of Economics and Political Science 29 (1963): 475-485.

Mundell, R.A. "A theory of optimum currency areas," American Economic Review 51 (1961): 657-665. 
Ndambendia, H. and Al-Hayky, A. "Effective exchange rate volatility and Economic growth in Sub-Saharan Africa: Evidence from panel unit root and cointegration tests," The IUP Journal for Applied Finance 17 (2011): 85-94.

Perée, E., and Steinherr, A. "Exchange rate uncertainty and foreign trade." European Economic Review 33 (1989): 1241-64.

Pino, G., Tas, D. and Sharma, S.C. "An investigation of the effects of exchange rate volatility on exports in East Asia," Applied Economics 48 (2016): 2397-2411.

Pozo, S. "Conditional exchange rate volatility and the volume of international trade: Evidence from the Early 1990s," Review of Economics and Statistics 74 (1992): 325-329.

Roodman, D. "How to do xtabond2: An introduction to "Difference" and "System" GMM in Stata," Stata Journal 9 (2009): 86-136.

Sachs, J.D. and Warner, A. "Economic reform and the process of global integration," Brookings Papers on Economic Activity 26 (1995): 1-118.

Schnabl, G. "Exchange rate volatility and growth in small open economies at the EMU periphery," Economic Systems 32 (2008): 70-91.

Schnabl, G. "Exchange rate volatility and growth in emerging Europe and East Asia," Open Economic Review 20 (2009): 565-587.

Servén, L. "Irreversibility, uncertainty and private investment: Analytical issues and some lessons for Africa," Journal of African Economies 6 (1997): 229-268.

Servén, L. "Macroeconomic uncertainty and private investment in LDCs: An 
empirical investigation," World Bank Policy Research Working Paper No. 2035 (1998).

Servén, L. "Real exchange rate uncertainty and private investment in LDCs,"Review of Economics and Statistics 85 (2003): 212-218.

Sharifi-Renani, H. and Mirfatah, M. "The impact of exchange rate volatility on foreign direct investment in Iran," Procedia Economics and Finance 1 (2012): 365-373.

Soleymani, A. and Chua, S.Y. "How responsive are trade flows between Malaysia and China to the exchange rate? Evidence from industry data,"International Review of Applied Economics 28 (2014): 191-209.

Tharakan, H. "Economic growth and exchange rate uncertainty," Applied Economics 31 (1999): 347-358.

Vanelle, V. "L'impact de la volatilité des taux de change sur le commerce international: L'apport des études empiriques," Economie Appliquée 54 (2001): 59-90.

Vieira, F.V. and MacDonald, R. "Exchange rate volatility and exports: a panel data analysis," Journal of Economic Studies 43 (2016): 203-221.

Vieira, F.V., Holland, M. Gomes Da Silva, C. and Bottecchia, L.C. "Growth and exchange rate volatility: a panel data analysis," Applied Economics 45 (2013): 3733-3741

Windmeijer, F. "A finite sample correction for the variance of linear efficient Twostep GMM estimator," Journal of Econometrics 126 (2005): 25-51.

Wong, H.T. "Exchange rate volatility and bilateral exports of Malaysia to 
Singapore, China, Japan, the USA and Korea," Empirical Economics 53 (2017): 459-492.

Zmami, M. and Ben-Salha, O. "Exchange rate movements and manufacturing employment in Tunisia: Do different categories of firms react similarly?" Economic Change and Restructuring 48 (2015): 137-167. 


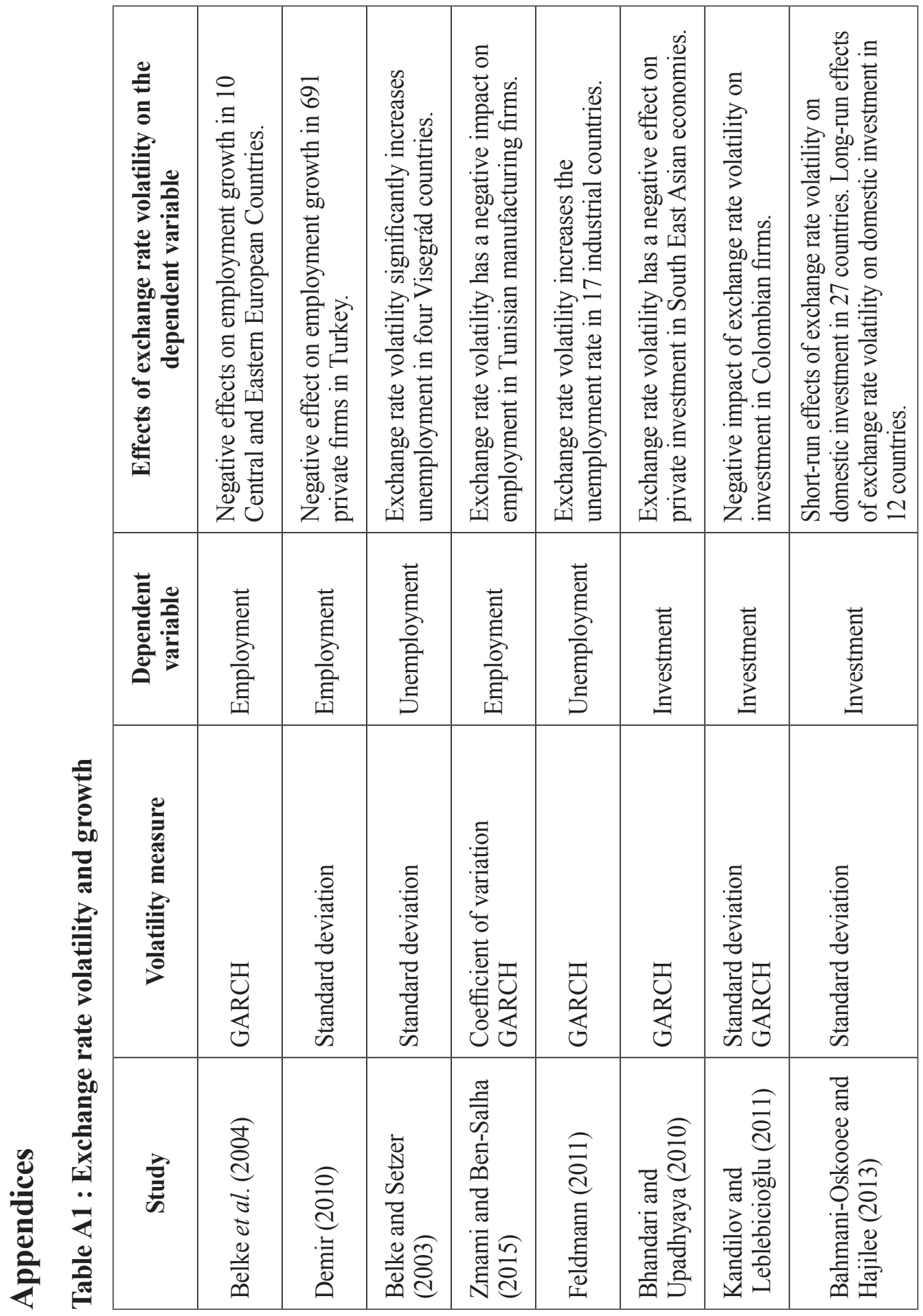




\begin{tabular}{|c|c|c|c|c|c|c|c|}
\hline 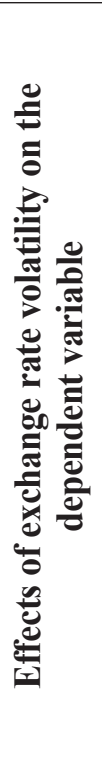 & 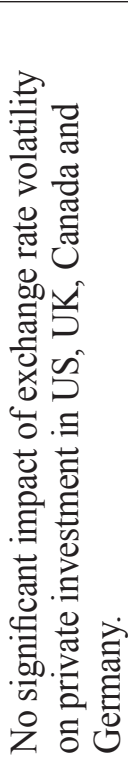 & 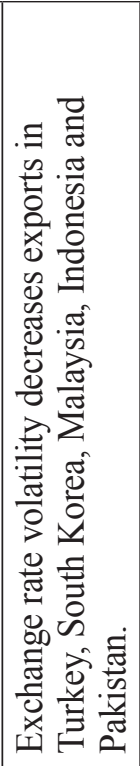 & 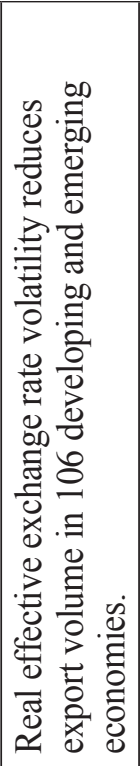 & 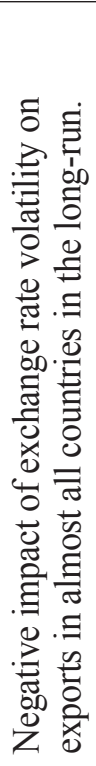 & 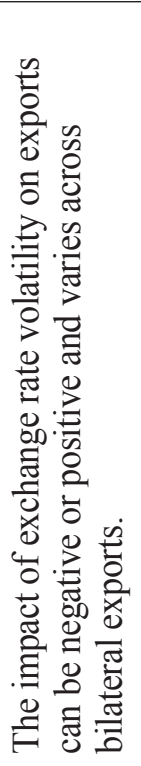 & 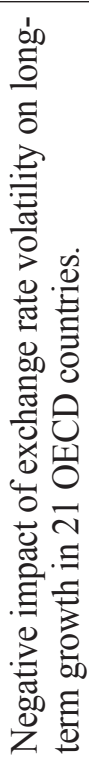 & 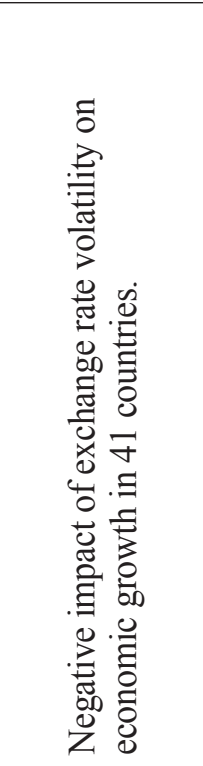 \\
\hline 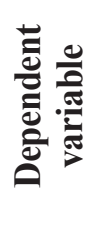 & 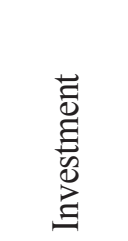 & 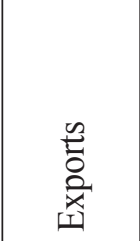 & 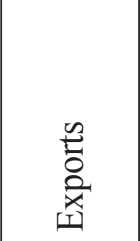 & 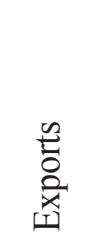 & 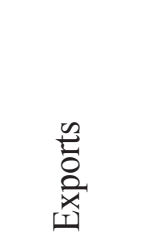 & 产 & 产 \\
\hline 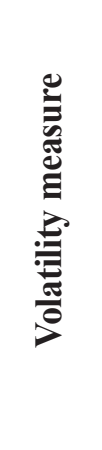 & 苾 & 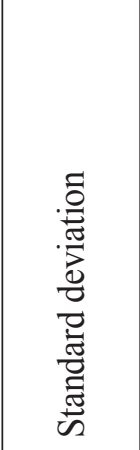 & 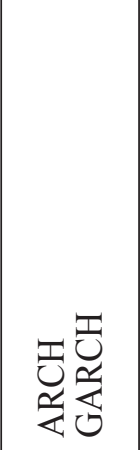 & 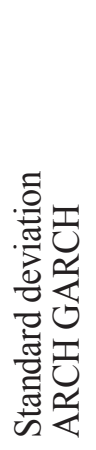 & 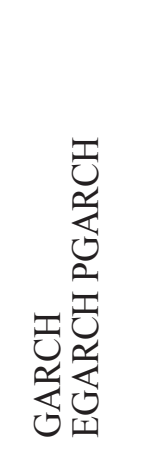 & 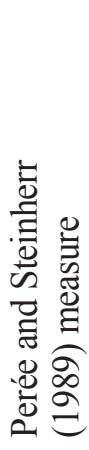 & 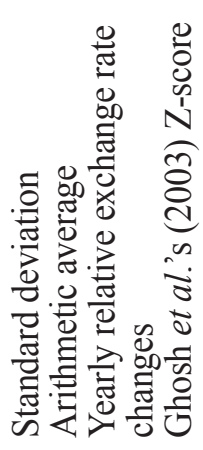 \\
\hline$\frac{\vec{E}}{E}$ & 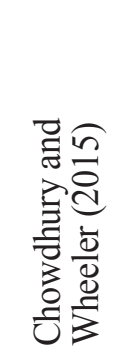 & 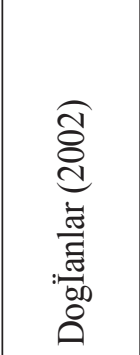 & 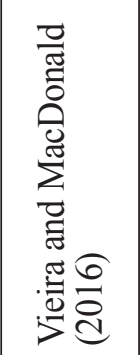 & 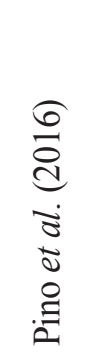 & 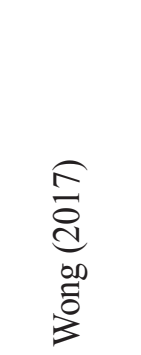 & 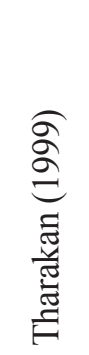 & 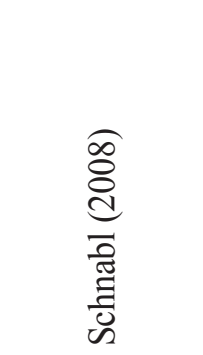 \\
\hline
\end{tabular}


导

\begin{tabular}{|c|c|c|c|c|c|c|}
\hline 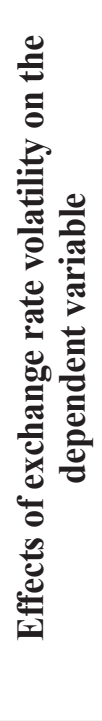 & 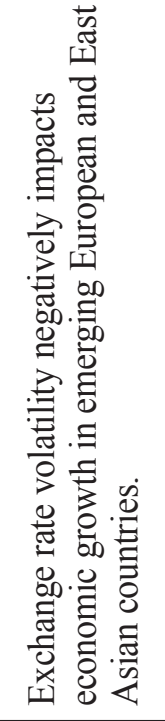 & 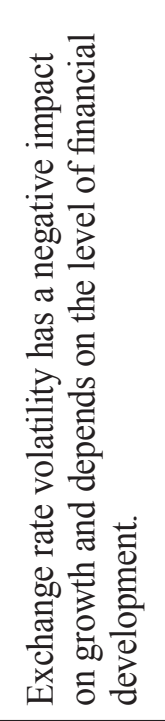 & 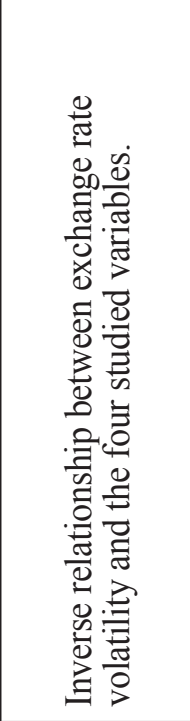 & 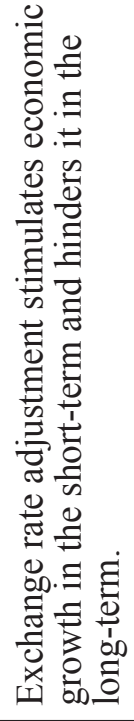 & 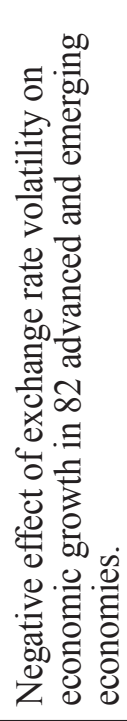 & 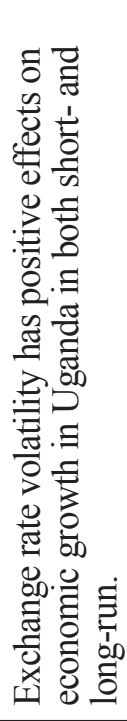 \\
\hline 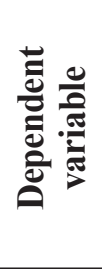 & 言 & 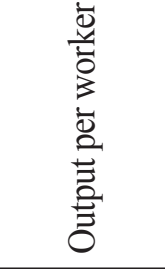 & 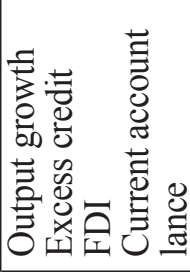 & 疍 & 苞 & 竞 \\
\hline 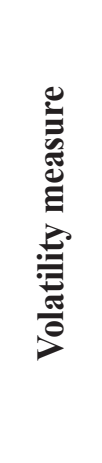 & 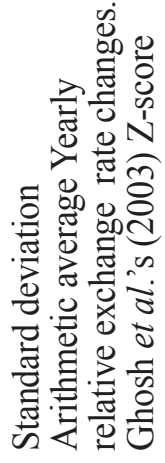 & 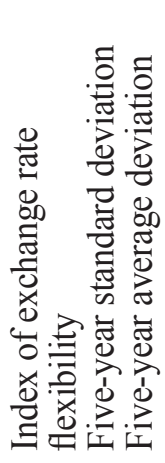 & 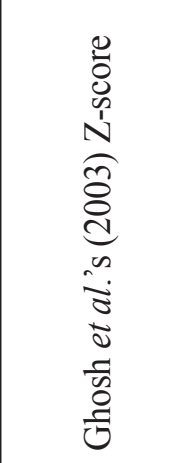 & 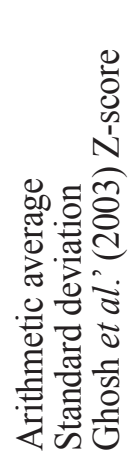 & 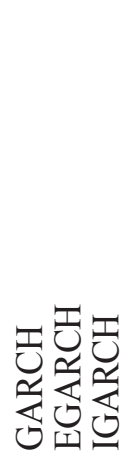 & 胥 \\
\hline 总 & 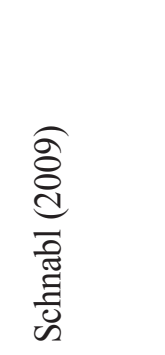 & 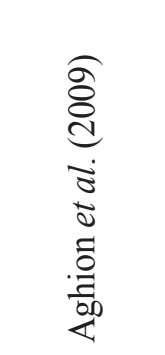 & 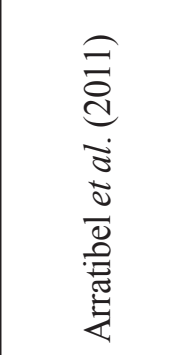 & 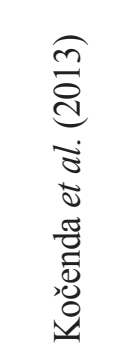 & 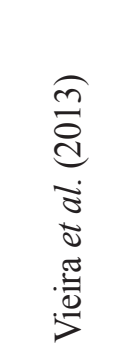 & 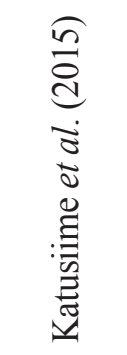 \\
\hline
\end{tabular}


Table A2 : List and classification of countries in the sample

\begin{tabular}{|l|c|c|c|c|}
\hline \multirow{2}{*}{ Countries } & \multicolumn{2}{|c|}{ Exchange rate regime } & \multicolumn{2}{c|}{$\begin{array}{c}\text { Degree of financial } \\
\text { openness }\end{array}$} \\
\cline { 2 - 5 } & Fixed & Flexible & LFO & MFO \\
\hline Algeria & & $\mathrm{X}$ & $\mathrm{X}$ & \\
\hline Antigua and Barbuda & $\mathrm{X}$ & & & $\mathrm{X}$ \\
\hline Bahamas & $\mathrm{X}$ & & $\mathrm{X}$ & \\
\hline Bahrain & $\mathrm{X}$ & & & $\mathrm{X}$ \\
\hline Belize & $\mathrm{X}$ & & & $\mathrm{X}$ \\
\hline Bolivia & & $\mathrm{X}$ & & $\mathrm{X}$ \\
\hline Brazil & & $\mathrm{X}$ & $\mathrm{X}$ & \\
\hline Burundi & & $\mathrm{X}$ & $\mathrm{X}$ & \\
\hline Cameroon & $\mathrm{X}$ & & $\mathrm{X}$ & \\
\hline Central African Republic & $\mathrm{X}$ & & $\mathrm{X}$ & \\
\hline Chile & & $\mathrm{X}$ & & $\mathrm{X}$ \\
\hline China & & $\mathrm{X}$ & & $\mathrm{X}$ \\
\hline Colombia & & $\mathrm{X}$ & $\mathrm{X}$ & \\
\hline Costa Rica & & $\mathrm{X}$ & & $\mathrm{X}$ \\
\hline Cote d'Ivoire & $\mathrm{X}$ & & $\mathrm{X}$ & \\
\hline Dominica & $\mathrm{X}$ & & & $\mathrm{X}$ \\
\hline Dominican Republic & & $\mathrm{X}$ & & $\mathrm{X}$ \\
\hline Equatorial Guinea & $\mathrm{X}$ & & $\mathrm{X}$ & \\
\hline Fiji & & $\mathrm{X}$ & $\mathrm{X}$ & \\
\hline Gabon & & & $\mathrm{X}$ & \\
\hline Gambia & & & $\mathrm{X}$ \\
\hline Ghana & & & \\
\hline Grenada & & & \\
\hline Guyana & & & \\
\hline
\end{tabular}


(continued)

\begin{tabular}{|c|c|c|c|c|}
\hline \multirow{2}{*}{ Countries } & \multicolumn{2}{|c|}{ Exchange rate regime } & \multicolumn{2}{|c|}{$\begin{array}{c}\text { Degree of financial } \\
\text { openness }\end{array}$} \\
\hline & Fixed & Flexible & LFO & MFO \\
\hline Lesotho & $\mathrm{X}$ & & X & \\
\hline Malawi & & $\mathrm{X}$ & $\mathrm{X}$ & \\
\hline Malaysia & & $X$ & & $\mathrm{X}$ \\
\hline Mexico & & $X$ & & $\mathrm{X}$ \\
\hline Nicaragua & & $\mathrm{X}$ & & $\mathrm{X}$ \\
\hline Nigeria & & $\mathrm{X}$ & $\mathrm{X}$ & \\
\hline Pakistan & & $\mathrm{X}$ & $\mathrm{X}$ & \\
\hline Papua New Guinea & & $\mathrm{X}$ & & $\mathrm{X}$ \\
\hline Paraguay & & $\mathrm{X}$ & & $\mathrm{X}$ \\
\hline Philippines & & $\mathrm{X}$ & & $X$ \\
\hline Saudi Arabia & $\mathrm{X}$ & & & $\mathrm{X}$ \\
\hline Sierra Leone & & $\mathrm{X}$ & $\mathrm{X}$ & \\
\hline Singapore & & $\mathrm{X}$ & & $\mathrm{X}$ \\
\hline South Africa & & $\mathrm{X}$ & $\mathrm{X}$ & \\
\hline Togo & $\mathrm{X}$ & & $\mathrm{X}$ & \\
\hline Trinidad and Tobago & & $\mathrm{X}$ & & $\mathrm{X}$ \\
\hline Tunisia & & $\mathrm{X}$ & $\mathrm{X}$ & \\
\hline Uganda & & $\mathrm{X}$ & & $\mathrm{X}$ \\
\hline Uruguay & & $\mathrm{X}$ & & $\mathrm{X}$ \\
\hline Venezuela & $\mathrm{X}$ & & & $\mathrm{X}$ \\
\hline
\end{tabular}

(Note) LFO and MFO stand for less financially open economies and more financially open economies. 